\title{
PENGUKURAN PROBABILITAS KEBANGKRUTAN OBLIGASI KORPORASI DENGAN SUKU BUNGA COX INGERSOLL ROSS MODEL MERTON (Studi Kasus Obligasi PT Indosat, Tbk)
}

\author{
Muhammad Akhir Siregar ${ }^{1}$, Mustafid ${ }^{2}$, Rukun Santoso. ${ }^{3}$ \\ 1,2,3 Departemen Statistika, Fakultas Sains dan Matematika, Universitas Diponegoro \\ makhirsir@gmail.com
}

\begin{abstract}
Nowadays bonds become one of the many securities products that are being prefered by investors. Observing the level of the company's rating which good enough or in the criteria of investment grade can't be a handle of investors. Investing in long-term period investors should understand the risks to be faced, one of investment credit risk on bonds is default risk, this risk is related to the possibility that the issuer fails to fulfill its obligations to the investor in due date. The measurement of the probability of default failure by the structural method approach introduced first by Black-Scholes (1973) than developed by Merton (1974). In Bankruptcy model, merton's model assumed the company get default (bankrupt) when the company can't pay the coupon or face value in the due date. Interest rates on the Merton model assumed to be constant values replaced by Cox Ingersoll Ross (CIR) rates. The CIR rate is the fluctuating interest rate in each period and the change is a stochastic process. The empirical study was conducted on PT Indosat, Tbk's bonds issued in 2017 with a face value of 511 Billion in payment of obligations by the issuer for 10 years. Based on simulation results done with $\mathrm{R}$ software obtained probability of default value equal to 7,416132E-215 Indicates that PT Indosat Tbk is deemed to be able to fulfill its obligation payment at the end of the bond maturity in 2027.
\end{abstract}

Keywords: Bond, CIR Rate, Merton Model, Ekuity, Probability of default

\section{PENDAHULUAN}

Obligasi merupakan surat utang dalam jangka panjang yang diterbitkan oleh suatu lembaga dengan nilai nominal dan waktu jatuh tempo tertentu (Astuti, 2003). Obligasi memberikan peranan yang cukup besar dalam perkembangan perekonomian perusahaan, penerbitan obligasi yang dinilai cukup efektif sebagai sumber pembiayaan bagi perusahaan dalam menjalankan ekspansi bisnis, memenuhi kebutuhan keuangan perusahaan, serta pengembalian modal terhadap investor dengan jangka waktu yang panjang.

Selain mendapatkan keuntungan, dalam melakukan investasi obligasi juga dapat memberikan tingkat potensi risiko investasi. Risiko ini disebut credit risk yaitu potensi risiko yang akan timbul bagi investor jika pihak penerbit obligasi (emiten) gagal membayar pokok obligasi atau kupon pada saat jatuh tempo.

Kegagalan pembayaran merupakan permasalahan kredit. Jorion (2009) mengatakan bahwa risiko gagal bayar adalah penggerak utama risiko kredit. Hal ini ditunjukan sebagai probabilitas kegagalan pembayaran. Pengukuran risiko kredit korporasi dimulai dari Merton (1974) dengan mengembangkan Model Black Scholes (Longstaff, 1995). Merton menggambarkan suatu perusahaan dikatakan bangkrut ketika pada saat jatuh tempo nilai aset perusahaan lebih kecil daripada nilai utang perusahaan, dengan asumsi perusahaan hanya menerbitkan satu obligasi berkupon nol (zero coupon bond).

Pada dunia ekonomi, tingkat suku bunga berpengaruh penting dalam penentuan harga suatu sekuritas, seperti pada penentuan harga obligasi. Asumsi model Merton yang menyatakan bahwa tingkat suku bunga selalu bernilai konstan dianggap kurang realistis, pada kenyataannya suku bunga selalu bergerak pada setiap waktunya mengikuti proses stokastik.

Suku bunga Model Cox Ingersoll Ross (CIR) merupakan suku bunga stokastik diperkenalkan pertama kali oleh Cox, Ingersoll, dan Ross pada tahun 1985 (Damir, 2009). Model CIR menjamin tingkat suku bunga bernilai positif dan memiliki sifat mean reversion 
yakni suatu keadaan ketika pergerakan tingkat bunga memiliki kecenderungan untuk kembali ke tingkat normal, sehingga tingkat bunga hanya bergerak pada range yang terbatas. Suku bunga CIR yang merupakan suku bunga stokastik akan menggantikan nilai suku bunga yang sebelumnya konstan pada asumsi dan perhitungan risiko kredit model Merton.

\section{TINJAUAN PUSTAKA}

\subsection{Obligasi}

Surat berharga obligasi merupakan instrumen utang bagi perusahaan yang hendak memperoleh modal. Perusahaan yang menerbitkan obligasi hanya mengakui utang kepada investor sebesar nilai pokok obligasi yang dimilikinya. Dalam struktur modal perusahaan obligasi dimasukkan dalam modal asing atau utang jangka panjang. Perusahaan tersebut mempunyai kewajiban untuk membayar utang dan pokok pinjaman sesuai dengan jangka waktu yang telah ditetapkan (Kasmir, 2012).

\subsection{Teori Tingkat Suku Bunga}

Suku bunga adalah harga yang dibayar peminjam (debitur) kepada pihak yang meminjamkan (kreditur) untuk pemakaian sumber daya selama interval waktu tertentu. Investor dapat menentukan suku bunga yang dapat dijadikan patokan sebelum membeli obligasi. Suku bunga yang dapat dijadikan benchmark terdiri atas berbagai jenis, salah satunya adalah suku bunga Sertifikat Bank Indonesia (SBI) dan BI rate. Pergerakan tingkat suku bunga SBI sangat berpengaruh terhadap efek pendapatan tetap.

\subsection{Konsep Dasar Statistik}

\subsubsection{Probabilitas}

Pada sebuah eksperimen, $S$ dinotasikan sebagai ruang sampel, yaitu himpunan dari semua kejadian yang mungkin pada suatu eksperimen dan $A, A_{1}, A_{2}, \ldots$. merepresentasikan sebagai kejadian yang mungkin muncul. $P(A)$ disebut sebagai probabilitas dari $A$ jika memenuhi sifat-sifat (Walpole, 1995) :
a. $P(S)=1$
b. $0 \leq P(A) \leq 1$
c. $P(\varnothing)=0$

\subsubsection{Variabel Random}

Variabel random adalah suatu fungsi yang mengaitkan suatu bilangan real pada setiap unsur dalam ruang sampel. Variabel random biasanya menggunakan lambang huruf besar seperti X, Y, atau Z. Ada dua jenis variabel random yaitu variabel random diskrit dan variabel random kontinu (Walpole dan Raymon, 1995).

\subsubsection{Distribusi Normal}

Sebuah variabel random kontinu $\mathrm{X}$ berdistribusi normal jika bergantung pada dua parameter mean $\mu$ dan variansi $\sigma^{2}$, dinyatakan $X \sim N\left(\mu, \sigma^{2}\right)$. Fungsi densitas probabilitas :

Dengan

$$
f(x ; \mu, \sigma)=\frac{1}{\sigma \sqrt{2 \pi}} e^{-\frac{1}{2}\left(\frac{x-\mu}{\sigma}\right)^{2}}
$$

$\mu \quad$ : mean dari $x$

$\sigma \quad$ : standar deviasi $x$

Untuk $(-\infty<x<\infty)$ dengan $(-\infty<\mu<\infty)$ dan $(0<\sigma<\infty)$ (Bain dan Engelhardt, 1992).

\subsubsection{Distribusi Lognormal}


Variabel random Y dikatakan mempunyai distribusi lognormal jika logaritma naturalnya $X=\ln (Y)$ mengikuti distribusi Normal.

$$
X=\ln (Y) \leftrightarrow Y=e^{x}
$$

Variabel random $\mathrm{Y}$ berdistribusi lognormal dengan mean $\mu$ dan variansi $\sigma^{2}$ atau $Y \sim \operatorname{LOGN}\left(\mu, \sigma^{2}\right)$ (Montgomery, 1990). Fungsi densitas dari Y adalah :

Untuk $(-\infty<\mu<\infty)$ dan $(0<\sigma<\infty)$

$$
f=\left\{\begin{array}{c}
\frac{1}{y \sigma \sqrt{2 \pi}} e^{-\frac{1}{2}\left(\frac{\ln y-\mu}{\sigma}\right)^{2}}, y>0 \\
0, y \leq 0
\end{array}\right.
$$

Sehingga variabel random $\mathrm{Y}$ mempunyai mean dan variansi :

\subsubsection{Proses Stokastik}

$$
\begin{gathered}
E(Y)=e^{\mu+\frac{1}{2} \sigma^{2}} \\
\operatorname{Var}(Y)=e^{2 \mu+\frac{1}{2} \sigma^{2}}\left(e^{\sigma^{2}}-1\right)
\end{gathered}
$$

Proses stokastik adalah himpunan variabel random $\{X(t), t \in T\}$ dengan $t$ menyatakan waktu dan $X(t)$ menyatakan proses pada waktu $t$, dan $X(t)$ disetiap pergerakan waktu $t$ memiliki nilai probability masing-masing. Himpunan $T$ disebut himpunan indeks dari suatu proses stokastik. Jika himpunan $T$ adalah himpunan terhitung $t \in[0, T]$, maka proses stokastik dikatakan sebagai proses stokastik waktu diskrit dan dinyatakan dalam bentuk $\{X(n) ; n=0,1,2, \ldots\}$. Jika himpunan $T$ adalah suatu interval waktu $t \in[0, \infty]$, maka proses stokastik dikatakan sebagai proses stokastik waktu kontinu dan dinyatakan dalam bentuk $\{X(t) ; t \geq 0\}$. (Taylor dan Karlin, 1998).

\section{a. Gerak Brown}

1. Gerak Brown (Proses Wiener)

Gerak Brown dinotasikan dengan $W_{t}$, Suatu proses stokastik $\left\{W_{t} ; t>0\right\}$ disebut Gerak Brown jika memenuhi sifat -sifat berikut :

a. $W_{t}$ adalah fungsi kontinu dalam $\mathrm{t}$

b. $W_{0}=0$

c. Setiap perubahan $W_{t}-W_{s}$ adalah berdistribusi normal dengan mean 0 dan varians $\sigma^{2}(t-s)$ untuk $0 \leq s \leq t \leq T$

d. Untuk setiap $0 \leq s \leq t \leq T$ dan $0 \leq u \leq v \leq T ; W_{t}-W_{s}$ dan $W_{v}-W_{u}$ adalah variabel acak yang saling bebas.

2. Gerak Brown Standar

Suatu Gerak Brown dengan $\mu=0$ dan $\sigma^{2}=1$, disebut gerak brown standar (baku). Suatu proses stokastik $\left\{W_{t} ; t>0\right\}$ disebut Gerak Brown Standar jika memenuhi sifat -sifat berikut :

a. $W_{t}$ adalah fungsi kontinu dalam $\mathrm{t}$

b. $W_{0}=0$

c. Setiap perubahan $W_{t}-W_{s}$ adalah berdistribusi normal dengan mean 0 dan varians $(t-s)$ untuk $0 \leq s \leq t \leq T$, atau secara ekuivalen $W_{t}-W_{s} \sim \sqrt{t-s} N(0,1)$.

d. Untuk setiap $0 \leq s \leq t \leq T$ dan $0 \leq u \leq v \leq T$; $W_{t}-W_{s}$ dan $W_{v}-W_{u}$ adalah variabel acak yang saling bebas.

3. Gerak Brown dengan suku drift

Gerak Brown dengan suku drift mempunyai persamaan sebagai berikut :

$$
B(t)=\mu(t)+\sigma W(t)
$$


dengan $\mu(t)$ nilai rata-rata dan $\sigma$ adalah nilai standar deviasi proses $t$. $W(t)=$ $Z \sqrt{t}, Z$ adalah bilangan random dari distribusi Normal standar (Dmouj, 2006).

4. Gerak Brown Geometri

Menurut Dmouj (2006) Jika diberikan model Gerak Brown dengan suku drift $B(t)=\mu^{*}(t)+\sigma W(t) ; t \geq 0$ dengan parameter drift $\mu^{*}=\mu-\frac{1}{2} \sigma^{2}$, parameter variansi $\sigma^{2}$, dan $W(t)$ adalah proses Gerak Brown yang dimulai pada $W(0)=0$. Pada pergerakan harga aset, proses stokastik $\{V(t) ; t \geq 0\}$ disebut Gerak Brown Geometri jika $B(t)=\ln \frac{V(t)}{V(t-1)}$, dengan $B(t)$ merupakan return aset pada waktu ke $t$.

b. Persamaan Diferensial Stokastik

1. Lemma Ito

Jika terdapat variabel $X(t)$ yang mengikuti proses Ito dengan Persamaan Diferensial Stokastik:

$$
d X(t)=\mu(X, t) d t+\sigma(X, t) d W(t)
$$

Dimana $W(t)$ adalah Gerak Brown serta $\mu$ dan $\sigma$ adalah parameter dari $X$ dan $t$, Teorema Ito menyebutkan bahwa, jika terdapat fungsi $F=F(X, t)$, maka fungsi $F$ akan mengikuti persamaan berikut (Hull, 2003) :

2. Integral Ito

$$
d F=\left(\frac{\delta F}{\delta X(t)} \mu+\frac{\delta F}{\delta t}+\frac{1}{2} \frac{\delta^{2} F}{\delta X(t)^{2}} \sigma^{2}\right) d t+\frac{\delta F}{\delta X(t)} \sigma d W(t)
$$

Integral stokastik Ito $\int_{0}^{T} X(t) d W(t)$ dari proses sederhana deterministik, didefenisikan sebagai $\int_{0}^{T} X(t) d W(t)=\sum_{i=0}^{n-1} c_{l}\left[W\left(t_{i+1}\right)-W\left(t_{1}\right)\right]$. Terdapat sifatsifat dari Integral stokastik Ito untuk proses sederhana sebagai berikut:

a. Linear, Misalkan $X(t)$ dan $Y(t)$ adalah proses sederhana dan $\mu, \sigma$ merupakan konstanta, maka:

$$
\int_{0}^{T}(\mu X(t)+\sigma Y(t)) d W(t)=\mu \int_{0}^{T} X(t) d W(t)+\sigma \int_{0}^{T} Y(t) d W(t)
$$

b. Ekspektasi dari Integral stokastik Ito adalah nol, yaitu:

$$
E\left[\int_{0}^{T} X(t) d W(t)\right]=0
$$

c. Integral stokastik memenuhi sifat isometrik, yaitu:

$$
E\left[\left(\int_{0}^{T} X(t) d W(t)\right)^{2}\right]=E\left[X^{2}(t)\right] d t \text {, untuk } t \in[0, T]
$$

\subsubsection{Ordinary Least Square (OLS)}

Ordinary Least Square (OLS) (Drapper dan Smith, 1992) adalah metode estimasi didalam ilmu stastistika yang meminimalkan jumlahan kuadrat dari error. Dalam OLS errornya diasumsikan identik, independen dan berdistribusi normal dengan mean nol dan varian konstan. Misalkan diberi suatu model:

$$
Y_{t}=\theta X_{t}+e_{t}, \quad t=1,2, \ldots, n
$$

Dengan $e_{t}$ adalah bagian error dan nilai ekspektasinya adalah nol. $E\left[e_{t}\right]=0$. Maka Estimator untuk koefisien $\theta$ Pada Persamaan (2.5) adalah:

\subsection{Model Merton}

$$
\hat{\theta}=\frac{\sum_{t=1}^{n} X_{t} Y_{t}}{\sum_{t=1}^{n} X_{t}^{2}}
$$

Model Merton mengadopsi asumsi struktur modal sederhana suatu perusahaan yaitu liabilitas dan ekuitas. Asumsi penting dari model Merton adalah perusahaan hanya mempunyai satu obligasi kupon nol dalam periode obligasi. Model Merton adalah suatu 
model yang digunakan untuk menilai utang korporasi dengan nilai pasar ekuitas dan probability of default. Dengan mengasumsikan bahwa obligasi memiliki kupon nol (Zero Coupon Bond) dan perusahaan penerbit obligasi tidak memiliki utang yang lain, Merton menunjukkan kemungkinan gagal bayar terjadi pada saat jatuh tempo.

Menurut (Kulkarni dan Jigisha, 2006) asumsi yang mendasari model Merton adalah sebagai berikut:

1. Dinamik nilai total aset perusahaan mengikuti persamaan diferensial stokastik :

dimana

$$
d V_{t}=\mu V_{t} d_{t}+\sigma V_{t} d W_{t}
$$

$V_{t} \quad$ : Nilai total aset perusahaan pada waktu $t$

$\mu \quad$ : Drift atau harga harapan dari return dalam perusahaan per unit waktu

$\sigma \quad$ : Volatilitas dari $V_{t}$

$W_{t} \quad$ : Proses Wiener standar yang merupakan gerak brown dengan rataan 0 dan varian 1 .

2. Dinamik suku bunga mengikuti suku bunga CIR, diberikan :

$$
d r(t)=\alpha(\beta-r(t)) d t+\sigma \sqrt{r(t)} d W(t)
$$

dimana

$d r(t) \quad$ : Perubahan tingkat suku bunga pada interval waktu yang pendek

$\alpha \quad$ : Kecepatan dari mean reversion

$\beta \quad$ : Menyatakan rata-rata tingkat bunga dalam jangka waktu panjang

$r(t) \quad$ : Tingkat suku bunga pada waktu $t$

$\sigma \quad$ : Menyatakan variansi dari perubahan tingkat bunga persatuan waktu

$\{W(t), t \geq 0\}$ : Proses Wiener atau Gerak Brown standar

3. Kewajiban dari perusahaan hanya terdiri dari utang tunggal dengan suatu nilai utang muka (face value), utang diasumsikan tidak memiliki kupon.

4. Proses nilai total aset perusahaan mengikuti distribusi log normal atau Gerak Brown Geometrik.

5. Kebangkrutan hanya dapat terjadi saat jatuh tempo.

6. Prioritas mutlak dari klaim didahulukan ketika perusahaan mengalami default.

7. Tidak ada biaya transaksi, pajak atau permasalahan dengan aset.

8. Dimungkingkan terjadinya short selling setiap waktu.

\subsection{Suku Bunga Model Cox, Ingersoll, dan Ross (CIR)}

Model tingkat suku bunga CIR mempunyai bentuk model yang mengikuti persamaan diferensial stokastik. Model CIR menjamin tingkat suku bunga bernilai positif dan memiliki sifat mean reversion atau mempunyai kecendrungan kembali menuju rata-rata. Bentuk dari model CIR adalah:

$$
d r(t)=\alpha(\beta-r(t)) d t+\sigma \sqrt{r(t)} d W(t)
$$

Nilai ekspektasi suku bunga CIR diperoleh dengan algoritma sebagai berikut:

1. Menentukan estimator CIR dari $\alpha$ menggunakan persamaan

$$
\hat{a}=-\frac{1}{\Delta t} \ln \left(\frac{\sum_{t=1}^{n}\left(r_{t}-\bar{r}_{t}\right)\left(r_{t-1}-\bar{r}_{t-1}\right)}{\sum_{t=1}^{n}\left(r_{t-1}-\bar{r}_{t-1}\right)^{2}}\right)
$$

2. Menentukan estimator CIR dari $\beta$ menggunakan persamaan

$$
\hat{\beta}=\frac{\bar{r}_{t}-e^{-\alpha \Delta t} \bar{r}_{t-1}}{1-e^{-\alpha \Delta t}}
$$

3. Setelah diperoleh masing-masing estimator dari CIR dan diketahui $r_{0}$ kemudian menghitung $r_{1}$ menggunakan persamaan

$$
E_{\theta}\left[r_{t} \mid r_{t-1}=r\right]=r_{c}=\gamma_{0}+\gamma_{1} r_{t-1}
$$


dengan $\gamma_{0}=\beta\left(1-e^{-\alpha \Delta t}\right)$ dan $\gamma_{1}=e^{-\alpha \Delta t}$

4. Untuk menentukan variansi tingkat suku bunga CIR $\sigma$ dengan menggunakan persamaan

$$
\hat{\sigma}^{2}=\frac{\frac{1}{n} \sum_{t=1}^{n}\left[\left(\widehat{\eta}_{0}+\widehat{\eta}_{1} r_{t-1}\right)\left(r_{k}-\left(\gamma_{0}+\gamma_{1} r_{t-1}\right)\right)^{2}\right]}{\frac{1}{n} \sum_{t=1}^{n}\left(\widehat{\eta}_{0}+\widehat{\eta}_{1} r_{t-1}\right)^{2}}
$$

kemudian nilai $\hat{\sigma}^{2}$ disubstitusikan ke persamaan untuk mencari nilai varian:

$$
\operatorname{Var}(r(t))=\sigma^{2}\left(\eta_{0}+\eta_{1} r(0)\right)
$$

dengan $\eta_{0}=\frac{\beta}{2 \alpha}\left(1-e^{-\alpha \Delta t}\right)^{2}, \eta_{1}=\frac{1}{\alpha} e^{-\alpha \Delta t}\left(1-e^{-\alpha \Delta t}\right)$.

\subsection{Risiko Kredit Korporasi}

Risiko kredit adalah risiko kerugian yang berhubungan dengan peluang counterparty gagal memenuhi kewajibannya pada saat jatuh tempo (Ghozali, 2007). Sedangkan risiko kredit korporasi meliputi risiko gagal bayar pada utang yang diterbitkan oleh suatu perusahaan/korporasi. Pada kondisi terburuk, perusahaan akan dilikuidasi untuk membayar utangnya. Dari hasil analisis akan dilihat kecendrungan kinerja ke depan yang berguna dalam pengambilan keputusan pemberian kredit.

\subsection{Volatilitas}

Volatilitas adalah besarnya nilai fluktuasi sebuah asset (Maruddani dan Purbowati, 2009). Jika terdapat $\mathrm{n}$ (jumlah observasi) return, maka nilai ekspektasi return dapat diestimasi dengan rata-rata sampel (sampel mean) return :

$$
\begin{aligned}
& \ln R_{t}=\ln \left(\frac{V_{t}}{V_{t-1}}\right) \\
& \overline{\ln R_{t}}=\frac{1}{n} \sum_{t=1}^{n} \ln R_{t}
\end{aligned}
$$

nilai rata-rata $\log$ return digunakan untuk mengestimasi variansi tiap periode yaitu:

$$
s^{2}=\hat{\sigma}^{2}=\frac{1}{n-1} \sum_{t=1}^{n}\left(\ln R_{t}-\overline{\ln R_{t}}\right)^{2}
$$

akar variansi (standar deviasi) merupakan estimasi nilai volatilitas harga aset.

\subsection{Nilai Aset Perusahaan}

Perhitungan modal atau aset suatu perusahaan model Merton dimasa yang akan dating, nilainya dapat diperkirakan dengan persamaaan:

$$
V_{T}=V_{t} \exp \left\{\left(\mu-\frac{1}{2} \sigma^{2}\right)(T-t)+\sigma \varepsilon \sqrt{(T-t)}\right\}, W_{t}=\varepsilon \sqrt{(T-t)}
$$

\subsection{Penentuan Nilai Pasar Ekuitas}

Didefenisikan bahwa $E\left(V_{T}, 0\right)$ sebagai nilai pasar ekuitas perusahaan hari ini (waktu ke-t) dan $V_{0}$ sebagai aset/nilai perusahaan pada saat $t=0$. Misal $E_{T}$ dan $V_{T}$ merupakan nilai masing-masing pada saat jatuh tempo $T$, ketika utang dengan nilai utang muka $K$ harus dibayarkan, maka nilai pasar ekuitas perusahaan adalah:

Tabel 1. Payoff atau Ekuitas pada Saat Jatuh Tempo

\begin{tabular}{|c|c|c|c|}
\hline Keadaan & Aset & Obligasi & Ekuitas \\
\hline Tidak Bangkrut & $V_{T} \geq K$ & $K$ & $V_{T}-K$ \\
\hline Bangkrut & $V_{T}<K$ & $V_{T}$ & 0 \\
\hline
\end{tabular}

Sumber : A.Longstaff dan S.Schwartz (1995)

Apabila ditulis secara umum, nilai pasar ekuitas model Merton adalah : 


$$
E_{T}\left\{\begin{array}{lr}
V_{T}-K \text { jika } V_{T} \geq K \\
0 \quad \text { jika } V_{T}<K
\end{array}\right.
$$

atau $E_{T}=\max \left[V_{T}-K, 0\right]$

Jika nilai ekuitas perusahaan dengan nilai utang (face value). $K$, adalah

$$
E_{\text {merton }}=\exp \left(-r_{c}(T-t)\right) E\left[\max \left[V_{T}-K, 0\right]\right]
$$

Jika $V_{T}$ berdistribusi Log Normal, maka $X=\ln \left(V_{T}\right)$ berdistribusi Normal, maka $X=$ $\ln \left(V_{T}\right) \sim N\left(\mu, \sigma^{2}\right)$ sehingga $V_{T} \sim L N\left(\mu_{l}, \sigma_{l}^{2}\right)$, dengan $\mu_{l}$ adalah nilai harapan dari $\ln V_{T}$, $\sigma_{l}^{2}$ adalah variansi dari $\ln V_{T}$, dan $l$ adalah index yang menyatakan bahwa variabel berdistribusi Lognormal. Maka nilai pasar ekuitas adalah:

$$
E_{\text {merton }}=V_{t} \Phi\left(d_{1}\right)-K \exp \left(-r_{c}(T-t)\right) \Phi\left(d_{2}\right)
$$

dengan :

$$
\begin{aligned}
& d_{1}=\frac{\ln \left(\frac{V_{t}}{K}\right)+\left(r_{c}+\frac{1}{2} \sigma^{2}\right)(T-t)}{\sigma \sqrt{(T-t)}} \\
& d_{2}=\frac{\ln \left(\frac{V_{t}}{K}\right)+\left(r_{c}-\frac{1}{2} \sigma^{2}\right)(T-t)}{\sigma \sqrt{(T-t)}}
\end{aligned}
$$

dimana

$E_{\text {merton }} \quad:$ Nilai ekuitas perusahaan model Merton

$V_{t} \quad:$ Nilai total aset perusahaan pada waktu ke $-t$

$V_{T} \quad:$ Nilai total aset perusahaan pada waktu ke $-T$

$K \quad$ : Nilai utang (face value) atau nilai obligasi

$r_{c} \quad:$ Suku bunga CIR

$\Phi(\cdot) \quad$ : Fungsi distribusi normal standar kumulatif

$(T-t) \quad$ : Waktu hingga jatuh tempo

$\sigma \quad$ : Volatilitas dari $V_{t}$

\subsection{Penentuan Nilai Liabilitas}

Liabilitas adalah hak dari pemberi hutang (kreditor) terhadap kekayaan perushaan (Darsono dan ashari, 2005). Penentuan Liabilitas diperoleh dari persamaan modal sederhana:

$$
\begin{aligned}
& V_{T}=F\left(V_{T}, T\right)+E\left(V_{T}, T\right) \\
& F\left(V_{T}, T\right)=V_{T}-E\left(V_{T}, T\right)
\end{aligned}
$$

dengan : $V_{T} \quad=$ Nilai total aset perusahaan pada waktu $T$

$F\left(V_{T}, T\right) \quad=$ Liabilitas perusahaan dalam waktu $T$

$E\left(V_{T}, T\right) \quad=$ Nilai Ekuitas perusahaan pada waktu $T$

\subsection{Probabilitas Kebangkrutan}

Probabilitas kebangkrutan adalah propabilitas dimana nilai total aset perusahaan kurang dari nilai utang muka (face value) pada saat jatuh tempo (Crosbie and Bohn, 2003). Jika diberikan bahwa perubahan nilai total aset perusahaan mengikuti persamaan diferensial stokastik: 
dimana

$$
d V_{t}=\mu V_{t} d \tau+\sigma V_{t} d W_{t}
$$

$V_{t} \quad$ : Nilai total aset perusahaan pada waktu $t$

$\mu \quad$ : Drift atau harga harapan return aset perusahaan per unit waktu

$\sigma \quad$ : Volatilitas dari $V_{t}$

$W_{t} \quad$ : Proses Wiener Standar

Jika diasumsikan bahwa perubahan aset mengikuti proses Wiener Standar, maka nilai total aset perusahaan pada periode $\tau$ adalah:

$$
V_{T}=V_{t} \exp \left\{\left(\mu-\frac{1}{2} \sigma^{2}\right)(T-t)+\sigma \varepsilon \sqrt{(T-t)}\right\}, W_{t}=\varepsilon \sqrt{(T-t)}
$$

atau

$$
\ln V_{T}=\ln V_{t}+\left\{\left(\mu-\frac{1}{2} \sigma^{2}\right)(T-t)+\sigma \varepsilon \sqrt{(T-t)}\right\}
$$

dengan $\varepsilon=$ sampel random berdistribusi normal $\varepsilon \sim N(0,1)$

sehingga probabilitas kebangkrutannya (PD) adalah (Maruddani dkk, 2015)

$$
\begin{gathered}
P D=P\left[V_{T}<K\right] \\
=\Phi\left[-\frac{\ln \frac{V_{t}}{K}+\left(\mu-\frac{1}{2} \sigma^{2}\right)(T-t)}{\sigma \sqrt{(T-t)}}\right]
\end{gathered}
$$

pada salah satu sifat gerak Brown, diasumsikan bahwa sampel berdistribusi normal dengan mean nol dan variansi satu, Sehingga bisa ditetapkan probabilitas kebangkrutan erat hubungannya dengan distribusi normal kumulatif dalam risk neutral probability. Harga drift adalah harga pada risk free rate dengan demikian harga drift $\mu$ dapat diganti oleh suku bunga $r_{c}$ (Kulkarni, 2006).

\section{METODE PENELITIAN}

\subsection{Sumber Data}

Data yang digunakan dalam penelitian ini adalah data sekunder, yaitu data suku bunga Bank Indonesia mulai bulan Januari 2006 - Desember 2017 dari website www.bi.go.id. Data obligasi PT Indosat, Tbk dengan kode obligasi ISAT02ECN2 yang diperoleh dari www.ibpa.co.id. Data aset perusahaan PT Indosat, Tbk mulai bulan Maret 2006 - September 2017 diperoleh dari www.assets.indosatooredoo.com.

\subsection{Langkah Analisis Data}

1. Memilih data obligasi perusahaan.

2. Menghitung nilai ln return aset perusahaan dan uji kenormalan data ln return aset dengan uji normalitas Kolmogorof-Smirnov.

3. Menghitung nilai volatilitas aset perusahaan.

4. Menentukan estimasi parameter $\hat{\alpha}, \hat{\beta}$, dan $\hat{\sigma}^{2}$ untuk dinamik suku bunga CIR.

5. Menentukan suku bunga short rate pada waktu ke- $t+1\left(r_{c}\right)$.

6. Menghitung nilai pasar ekuitas dan liabilitas perusahaan.

7. Menghitung probabilitas kebangkrutan dengan menggunakan model Merton. 


\section{HASIL DAN PEMBAHASAN}

\subsection{Uji Normalitas Data In Return}

Hasil uji normalitas data ln return aset PT Indosat, Tbk adalah:

Hipotesis:

$H_{0} \quad$ : Data ln return aset berdistribusi normal

$H_{1} \quad$ : Data ln return aset tidak berdistibusi normal

Statistik Uji:

$$
\begin{aligned}
& D=\sup _{x}\left|F_{0}(x)-F(x)\right| \\
& D=0,11468 \\
& p-\text { value }=0,5226
\end{aligned}
$$

Pada taraf signifikansi $\alpha=5 \% H_{0}$ diterima, karena nilai $D=0.11468$ dengan $p$-value $=$ $0,5226>\alpha=0,05$. Dapat disimpulkan bahwa data ln return aset berdistribusi Normal.

\subsection{Volatilitas Aset}

Nilai volatilitas aset perusahaan merupakan gambaran dari tingkat fuktuasi pergerakan harga aset yang tidak menentu (naik turunnya harga aset yang tidak beraturan) yang terjadi pada perusahaan. Volatilitas aset dapat dihitung dari estimasi standar deviasi data $\ln$ return aset perusahaan. Nilai volatilitas aset yang diperoleh dengan program $\mathrm{R}$ sebesar 0,04582381 atau 4,58 \% Hal ini menunjukkan nilai volatilitas aset PT Indosat, Tbk tergolong kecil atau tingkat fluktuasinya rendah, sehingga mengindikasikan bahwa kemungkinan untuk bangkrut juga kecil atau rendah.

\subsection{Estimasi Nilai Suku Bunga Cox Ingersoll Ross (CIR)}

$$
r_{t}=\gamma_{0}+\gamma_{1} r_{t-1}+\varepsilon_{t}
$$

\begin{tabular}{|c|c|c|}
\hline Tahun $(\boldsymbol{t})$ & $\boldsymbol{r}_{\boldsymbol{t}+\mathbf{1}}$ & Suku Bunga CIR \\
\hline 2017 & $r_{1}$ & 0,0425 \\
\hline 2018 & $r_{2}$ & 0,056394326 \\
\hline$\vdots$ & $\vdots$ & $\vdots$ \\
\hline 2026 & $r_{10}$ & 0,070126644 \\
\hline $\mathbf{2 0 2 7}$ & $r_{11}$ & $\mathbf{0 , 0 7 0 1 5 2 8 2 7}$ \\
\hline
\end{tabular}

Hasil prediksi $B I$ rate untuk tahun 2027 adalah sebesar 0,070152827 atau 7,015\% . Nilai tersebut merupakan hasil prediksi nilai suku bunga pada akhir periode habisnya jangka waktu obligasi. Nilai suku bunga hasil prediksi pada tahun 2027 akan digunakan sebagai suku bunga CIR

$r_{c}$ pada pembahasan model Merton.

\subsection{Pasar Ekuitas Model Merton}

dengan :

$$
E_{\text {merton }}=V_{t} \Phi\left(d_{1}\right)-K \exp \left(-r_{c}(T-t)\right) \Phi\left(d_{2}\right)
$$

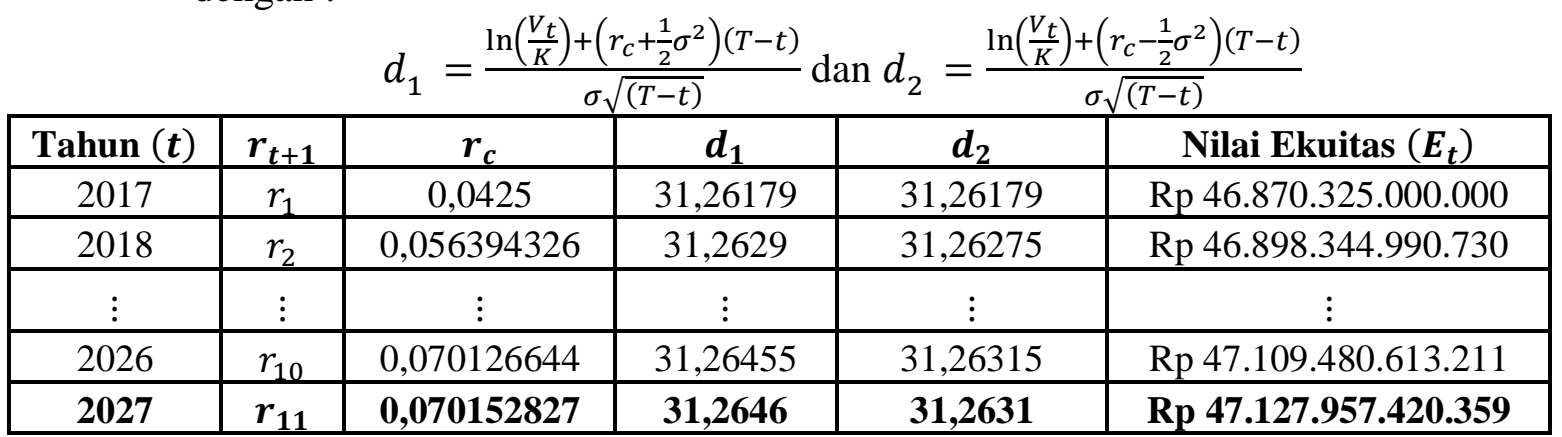


diperoleh estimasi nilai pasar ekuitas model Merton pada tahun berakhirnya jangka waktu obligasi dengan menggunakan suku bunga CIR $r_{11}=0,070152827$ senilai Rp. 47.127.957.420.359.

\subsection{Liabilitas}

\begin{tabular}{|c|c|c|c|}
\multicolumn{5}{|c|}{$F\left(V_{T}, T\right)=V_{T}-E\left(V_{T}, T\right)$} \\
\hline Tahun $(\boldsymbol{t})$ & $\boldsymbol{V}_{\boldsymbol{t}}$ Total Aset & $\boldsymbol{E}_{\boldsymbol{t}}$ Ekuitas & $\boldsymbol{F}_{\boldsymbol{t}}$ Liabilitas \\
\hline 2017 & $\mathrm{Rp} 47.381 .325 .000 .000$ & $\mathrm{Rp} .46 .870 .325 .000 .000$ & $\mathrm{Rp} 511.000 .000 .000$ \\
\hline 2018 & $\mathrm{Rp} 47.415 .739 .882 .965$ & $\mathrm{Rp} .46 .898 .344 .990 .730$ & $\mathrm{Rp} 517.394 .892 .235$ \\
\hline$\vdots$ & $\vdots$ & $\vdots$ & $\vdots$ \\
\hline 2026 & $\mathrm{Rp} 43.875 .691 .100 .310$ & $\mathrm{Rp} .47 .109 .480 .613 .211$ & $\mathrm{Rp}-3.233 .789 .512 .900$ \\
\hline $\mathbf{2 0 2 7}$ & Rp 56.061.242.515.914 & Rp. 47.127.957.420.359 & Rp 8.933.285.095.555 \\
\hline
\end{tabular}

estimasi nilai ekuitas untuk setiap tahunnya selalu lebih besar dari pada nilai liabilitas perusahaan meskipun sempat mengalami penurunan nilai aset pada beberapa tahun. dengan melihat pergerakan kedua nilai tersebut PT Indosat, Tbk tidak akan mengalami kebangkrutan. Sehingga pada waktu berakhirnya obligasi, nilai face value sebesar Rp. 511.000.000.000 yang ditawarkan pada penerbitan obligasi dapat dilunasi oleh PT Indosat, Tbk.

\subsection{Probabilitas Kebangkrutan (Probability of Default)}

$$
\begin{gathered}
P D=P\left[V_{T}<K\right] \\
=\Phi\left[-\frac{\ln \frac{V_{t}}{K}+\left(r_{c}-\frac{1}{2} \sigma^{2}\right)(T-t)}{\sigma \sqrt{(T-t)}}\right]=\Phi\left[-d_{2}\right] \\
\text { dengan diketahui nilai } d_{2}=31,2631 \text { diperoleh, }
\end{gathered}
$$$$
\begin{gathered}
P D=\Phi\left[-d_{2}\right] \\
P D=1-\Phi\left[d_{2}\right] \\
=1-1 \\
=0
\end{gathered}
$$

perhitungan digunakan fungsi NORMDIST pada software Excel lampiran 7, dan menggunakan program $R$ diperoleh nilai probabilitas sebesar 7,416132E-215 $\approx 0$. Nilai probabilitas kebangkrutan PT Indosat, Tbk sebesar 7,416132E-215 yang menunjukkan PT Indosat, Tbk untuk mengalami kebangkrutan adalah sangat kecil.

\section{KESIMPULAN}

Pemodelan suku bunga BI rate menggunakan suku bunga CIR dapat menghasilkan estimasi prediksi suku bunga yang diasumsikan bebas risiko. Nilai suku bunga model CIR yang didapatkan dari perhitungan BI rate adalah sebesar 7,015 \% pada tahun 2027. Dari uji normalitas Kolmogorov-Smirnov, didapatkan hasil bahwa data ln return aset PT Inodasat, Tbk berdistribusi normal karena nilai $\mathrm{p}$-value $=0,5226>\alpha=0,05$. Volatilitas PT Indosat, Tbk sebesar 4,58\% dinilai sangat kecil, hal ini berarti bahwa tingkat fluktuasi aset rendah dan kemungkinan untuk bangkrut juga kecil.

Didapatkan nilai probabilitas kebangkrutan yang sangat kecil yaitu sebesar $7,416132 E-215 \approx 0$. Dengan perkiraan nilai pasar ekuitas pada masa jatuh tempo obligasi sebesar Rp. 47.127.957.420.359,00 PT Indosat, Tbk dianggap masih mampu untuk membayar nilai pokok obligasi (face value) senilai Rp. 511.000.000.000,00 karena masih memiliki modal dan kekayaan yang cukup, dengan kata lain risiko kredit yang dihadapi para 
investor juga sangat kecil. Sehingga didapatkan kesimpulan bahwa PT Indosat, Tbk mempunyai kinerja perusahaan yang sangat bagus sesuai dengan rating kredit yang cukup bagus dan tidak adanya peluang untuk bangkrut jika dihitung dengan pemodelan risiko kredit model Merton.

\section{DAFTAR PUSTAKA}

Astuti, S. 2003, "Pengaruh Laporan Keuangan Terhadap Peringkat Hutang (Bond Rating) Studi empiris Pada Perusahaan di Bursa Efek Jakarta”, Wahana, Vol. 6 No. 2, p. 105-112.

Bain, L.J dan M. Engelhardt. 1992, Introduction to Probability and Mathematical Statistics 2nd Edition. California. Duxbury Press.

Bank Indonesia. Suku Bunga Bank Indonesia, BI Rate. www.bi.go.id. Diakses: 18 januari 2018 .

Conover.W.J. 1980. Practical Nonparametric Statistics. Newyork; John Wiley and Sons.

Cox J.C., Ingersoll J.E., and Ross S.A .1985, A Theory of the Term Structure of Interest Rates, Econometrica, Vol. 53, Issue 2, 385-406

Crosbie, P and J. Bohn. 2003. Modelling Default Risk. Moody's KMV Company. South America.

Darsono dan Ashari. 2005. Pedoman Praktis Memahami Laporan Keuangan. Jakarta: Salemba Empat

Departemen Keuangan RI. 1990. Salinan Kementrian Keuangan No:1548/KMK.013/1990 Tentang Pasar Modal Pasal 1 Ayat 34. www.depkeu.go.id. Diakses: 18 Januari 2018

Dmouj, A. 2006. Stock Price Modelling : Theory and Practice. Amsterdam : BMI Paper.

Draper, N.R, dan Smith, H. 1998. Applied Regression Analysis, (3ed). New York: John Wiley and Sons.

Elizalde, A. 2005. Credit Risk II: Structural Models. Madrid. CMEFI. Emery, Douglas R., John D. Finnerty, dan John D. Stowe. 2004. Corporate Financial Management. 2nd Edition. Pearson education Inc. New Jersey.

Filipovic, Damir, 2009, Term-Structure Models, Springer-Verlag, New York

Ghozali, I. 2007. Manajemen Risiko Perbankan.Badan Penerbit Universitas Diponegoro. Semarang.

Hull, John. 2003. Options, Futures \& Other Derivative Securities Fifth Edition. PrenticeHall. New Jersey.

Indosat ooredoo. Laporan Keuangan PT Indosat, Tbk. www.assets.indosatooredoo.com. Diakses: 15 Januari 2018.

[IBPA]. Indonesia Bond Pricing Agency. Data Pasar Surat Utang, Obligasi dan Sukuk Korporasi www.ibpa.co.id. Diakses: 15 Januari 2018. 
Jorion, P. 2009. Financial Risk Manager Handbook FRM PART I / PART II. (6th ed.) The United State of America: Willey Finance.

Kasmir. 2012. Bank dan Lembaga Keuangan Lainnya. PT Raja Grafindo Persada. Jakarta.

Klimko,L.A. and P.I, Nelson. 1978. On Conditional Least Square Estimastion for Stochastic Process, Annals of Statistics 6, 629-642

Kulkarni, Kumar M. and Jigisha T. 2006. How Good Is Merton Model at Assessing Credit Risk? Evidence From India, National Institute of Bank Management. India.

Longstaff, F.A and E.S. Schwartz. 1995. The Journal of Finance : A Simple Approach to Valuting Risk Fixed and Floating Rate Debt. American Finance Association, Washington DC.

Manurung, A.H. 2006. Dasar-Dasar Investasi Obligasi. Elex Medai Komputindo. Jakarta.

Maruddani, D.A.I. dan Purbowati, A. 2009. Pengukuran Value At Risk pada Aset Tunggal dan Portofolio dengan Simulasi Monte Carlo. Media Statistika. Vol 2 (2), 93-104

Maruddani, D.A.I, D.Rosadi, Gunardi and Abdurakhman, Valuation of One Period Coupon Bond Based on Default TIme and Empirical Study in Indonesian Bond Data, Far East Journal of Mathematical Sciences (FJMS), Vol. 98, 2015, pp. 57-53

Montgomery, D.C. dan W.W. Hines. 1990. Edisi Kedua, Terjemahan Rudiansyah, Probabilitas dan Statistik dalam Ilmu Rekayasa Manajemen. Jakarta. UI Press.

Overback, L. dan Ryden, T., 1997, Estimation In The Cox-Ingersoll-Ross Model, Cambridge University Press, Cambridge.

Rahardjo, S. 2003. Panduan Investasi Obligasi. PT gramedia Pustaka Utama. Jakarta.

Taylor, Howard M. and Karlin, Samuel. 1998. An Introduction to Stochastic Modeling 3rd edition. Academic Press, USA.

Walpole, R.E dan R.H Myears.1995. Ilmu Peluang dan Statistika untuk Insinyur dan Ilmuwan. Institut Teknologi Bandung. Bandung. 